\title{
THE EFFECT OF STREET FOODS VENDORS PRACTICES ON THE SPREAD OF POLLUTANTS UNDER THE COVID-19 PANDEMIC IN ASWAN GOVERNORATE IN EGYPT
}

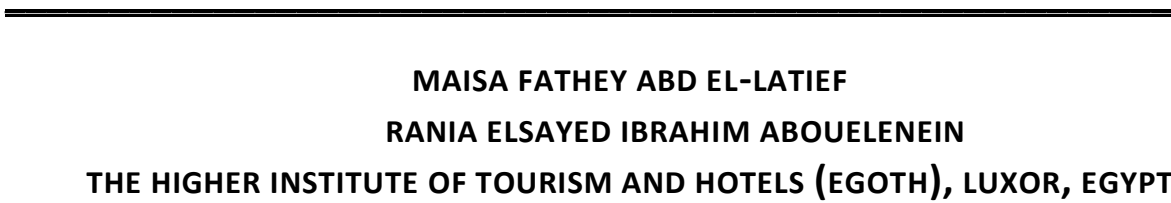

\section{Abstract}

Introduction: Street foods often reflect traditional local cultures to tourists and even to local consumers. With the increasing pace of globalization and tourism, the safety of street foods has become one of the major concerns of community health especially after the spread of viruses such as Corona Virus (COVID-19). Food handlers play an important role in the transmission of diseases. The study was conducted to evaluate food safety knowledge and practices of street vendors in Aswan city, using standardized survey tool to test food safety knowledge and practices of street food vendors. Aim: This research is aimed to determine the prevalence of COVID-19 among food handlers and its implications on the health of food consumers in Aswan city. Methods: A descriptive, crosssectional study utilizing a quantitative research approach. Especially questionnaire was designed allowed fast data collection. Data was collected through face-to-face interviewing of street food vendors, with observations of general hygiene and cleanliness. And also, an electronic questionnaire was designed and distributed to consumers. Descriptive analysis (frequency, percentage, mean) was performed using SPSS version 22.0. Results: No reliable standardized information is available regarding the numbers of street food vendors. The lowest ratings were found in the hygiene of food preparation and serving. A structured questionnaire was administered to (169) street vendors and (323) public consumers in Aswan. Most vendors are male (86.4\%). The study showed that the street food hygiene risks are primarily due to the unhealthy practices, poor infrastructure at the street food vending sites and lack of sanitation knowledge among street food vendors.

KEYwORDS: COVID-19, Street foods' vendors, Sanitation, Food safety, Practices, Food handlers, Hygiene. 


\section{INTRODUCTION}

Aswan is a city in the south of Egypt and is the capital of the Aswan Governorate (Smith and Melanie, 2016). Aswan is an eventful market and tourist center located just north of the Aswan Dam on the east bank of the Nile at the first cataract. The modernistic city has expanded and includes the previously separate community on the island of Elephantine. Aswan is a large tourist city where the current population is 1,568,000 (Giuffrida, 2019).

Globally, around 2.5 billion persons consume street food every day. There are improved attentions worldwide on the importance of street food as part of general concern for food security and health (WHO, 2020). The world is facing an unprecedented threat from the COVID-19 pandemic caused by the SARS-CoV-2 virus (referred to as the COVID-19 virus) (Tong et al., 2020). Many countries are following the advice from the World Health Organization (WHO) concerning the introduction of physical distancing measures as one of the ways in which transmission of the disease can be reduced (WHO, 2020). When COVID-19 outbreak begun, the transmission routes of the SARS-CoV-2 were not well understood (Yu et al., 2020). The known communication routes are the eyes, nose and mouth (Hamed and Mohammed, 2020). Street Food vendors with poor personal hygiene and inadequate information on food safety could be the source of food borne pathogens, especially the Corona virus (COVID-19) (WHO, 2020).

The Food and Agricultural Organization (FAO) was defined street foods as ready to-eat foods and beverages prepared and vended by vendors in streets and other similar community places (Thakur et al., 2013). Foods should therefore prepare in a relaxed setting and street food vendors are classified as informal food vendors (Samapundo et al., 2015). Street foods are perceived to be food is ready in unsanitary conditions by people not trained in proper food handling techniques (Rane, 2011). Street foods are normally ready-to-eat foods vended in stationary stalls, opened, semi closed or closed tables or by hawkers who roam about with the foods to find customers (Joanna et al., 2017).

Vendors are commonly found in colleges, at bus locations, government work places or workplaces, markets, social events, at places where major construction works is going on, by the windows of vehicles in heavy transportation and from door to door (Muinde and Kuria, 2005). These foods are generally prepared by vendors without training and certificates (Okojie and Isah, 2014). Those that are well- controlled and stationary have some oversight by the local authorities (Sani and Siow, 2014). 
It is extremely improbable that people can contract COVID-19 from food or food packaging. COVID-19 is a respiratory infection and the primary communication route is through person-to-person contact and through direct contact with respiratory droplets generated when an infected individual coughs or sneezes (WHO, 2020). There is no evidence to date of viruses that cause respiratory diseases being transmitted via food or food packaging (Yu et al., 2020). The virus can spread directly from person-toperson when a COVID-19 case coughs or sneezes, creating droplets that reach the nose, mouth, or eyes of another person (Hamed and Mohammed, 2020). Alternatively, as the respiratory droplets are too heavy to be airborne, they land on aims and surfaces surrounding the infected person (Tong et al., 2020). It is possible that somebody may become infected by moving an contaminated surface, object, or the hand of an infected person and then touching their own mouth, nose, or eyes. This can happen, for instance, when touching door knobs or shaking hands and then touching the face (Yu et al., 2020).

Individual protective equipment, such as masks and gloves, can be effective in falling the spread of viruses and disease within the street food vendors, but only if used properly (Zengran et al., 2014). The food production is strongly advised to introduce physical distancing and stringent hygiene and sanitation measures and promote frequent and effective hand washing and safety at each stage of food processing, manufacture and marketing (Woh et al., 2016). These measures will protect persons from spreading COVID-19 like what we found in $\mathrm{Yu}$ et al. (2020) study. In addition, the generally unregulated and destine street food production fends to observe poor hygienic practices (Son et al., 2015). The most important issue is for persons to be able to identify symptoms early so that they can seek appropriate medical care and testing, and minimize the danger of infecting fellow workers and consumers (Pokhrel et al., 2016). Within this context, epidemics have drawn increasing attention to street food's potential for illness transmission and have created growing backing for attempts to resolve these problems (Medical et al., 2016). This implies legal reorganization directed at structurally increasing street food vending and permitting application of measures that will foster good hygiene and safe foods (Iwu et al., 2017). Joanna et al. (2017) added that these factors including the lack of basic infrastructure, the diversity and large number of street food vending activities, the lowly knowledge of street vendors in basic safety measures and practices and the inadequate public realization of hazards.

The hygienic condition of the exemplary street vendors' dilapidated stalls, carts and equipment poses an obvious healthiness problem (Chada and 
Mamidi, 2012). In general the stalls and carts are constructed at the smallest possible charge using a minimum of construction technology (Bruce and colleen, 2013). This is a cause of great concern in view of the potential for making disease among consumers (Choudhury et al., 2011). Typically, toilet and lavatory services are not readily available, which forces the vendors and sometimes consumers to utilize any nearby areas available without washing their hands properly afterwards (Dun-Dery and Addo, 2016). Sale of food in the streets is very controversial from a health standpoint, because the poor hygienic practices associated with such food's preparation tend to pose significant health risks (Galgamuwa et al., 2016). Therefore, there must be awareness that street food can serve as a vehicle for disease transmission (Alekhya et al., 2017).

\section{METHODOLOGY}

\section{AIM OF THE STUDY}

This research is aimed to determine the prevalence of COVID-19 among food handlers and its implications on the health of food consumers in Aswan city.

\section{OBJECTIVES OF THE STUDY}

1- To describe the knowledge of street food vendors with regard to food hygiene and safety In light of the Corona pandemic.

2- To determine the attitudes of street food vendors toward food hygiene and safety In light of the Corona pandemic.

3- To identify the practices of street food vendors with regard to food hygiene and safety, and the impact on this on the spread of the Corona virus.

\section{Study SetTing}

The reason for choosing Aswan Governorate for the study is that it is among the first proposed governorates to open its doors for tourism in light of facing the Corona virus. This study is important to describe the knowledge, attitudes and practices of street food vendors, with regard to food hygiene and safety. Consumer confidence and regulatory control in street food vending can thus be achieved and the detrimental effects of COVID-19 incidents on the consumers as well as the city would be minimized. 


\section{Study Population}

The study population consisted of street food vendors selling cooked foods and the consumers in Aswan city.

\section{Materials AND Methods}

No reliable standardized information is available regarding the numbers of street food vendors. The targeted study sample for this study was (169) street vendors and (323) public consumers in Aswan. Face to face interviews utilizing a standardized questionnaire were carried out for street food vendors and distribute an electronic questionnaire to consumers from March to July 2020. In order to find respondents' attitude toward food safety, concerns and safety knowledge, a series of "Yes", "No". Besides, a five-point Likert rating scale, ranging from one (1) "strongly disagree" to five (5) "strongly agree" was also used to determine respondents' attitudes toward street foods safety and the risks of transmitting the Corona virus through wrong practices that could take place through street food vendors. Descriptive analysis (frequency, percentage, mean) was performed using SPSS version 22.0.

\section{STREeT FOOD Vendor's QUESTIONNAIRE}

No reliable standardized statistics is available regarding the numbers of street food vendors. The fast observation questionnaire used in this study allowed rapid assessment of implementation of hygiene principles. Based on field research in Aswan city, this study examines food quality and public hygiene with management of risk of food street vendors regarding COVID-19. The survey was conducted to evaluate the food safety knowledge and awareness of street food vendors in Aswan city, Egypt. (169) street food vendors operating on the major streets or near open air market and bus terminals were randomly chosen in the survey. The street foods the vendors sold were Dumplings, Cake, Bread, Kebabs, Handmade noodle, popular food, Hawawshi, liver, sausage, ice cream, mumbar, koshari, basbousa, licorice, sobia, grilled and fried fish, pickles, pastries, oriental sweets, vegetables and fruitlets. The questionnaire adopted to collect data was related to general food safety knowledge such as personal hygiene, foodborne illness, cross contamination, glove use, cleaning and sanitizing and food supervision practices. Inspections were carried out by direct and discreet, semi structured observation using a specially designed questionnaire allowing fast evaluation fast observation questionnaire. Interviews with employees were not carried out. The workers were not aware of the observation carried out, to not influence worker's attitudes during inspection. Each observation lasted $10 \mathrm{~min}$. 


\section{Consuming Public Questionnaire}

In order to investigate consumers' attitude towards street foods, motivation to buy street foods and food safety knowledge, a survey of (323) adult consumers conducted in Aswan city. The first section of the questionnaire is personal information related to gender, age, income, educational background and marital status. The second section is information on knowledge of the coronavirus and fears of it. The last section is on food sanitation knowledge, concerns and attitudes to food safety. In order to find respondents' attitude toward food safety, concerns and safety knowledge, a series of "Yes", "No". Besides, a five-point Likert rating scale, ranging from one (1) "strongly disagree" to five (5) "strongly agree" was also used to determine respondents' attitudes toward street foods safety and the risks of transmitting the Corona virus through wrong practices that could take place through street food vendors.

\section{RESULTS}

\section{First: AnAlysis of Street FoOd Vendors' Questionnaire}

Among food vendors included in the study, table (1) showed that $(36.1 \%)$ were aged less than 30 years, (52.7\%) between 31 and 40, and $(11.2 \%)$ aged above 41 years old. As regards educational level $(74 \%)$ educated to intermediate level, $(17.2 \%)$ educated to university level, $(86.4 \%)$ of them were males, this finding is similar to the findings of (Abdalla et al., 2009) where study revealed that all the food vendors were men, and the majority of them (40\%) at age group of 21-30 years. (70.4\%) of them from city, as regards their experience duration $(58.6 \%)$ of them had experience between 6 to 10 years, and (16.6\%) had experience more than 10 years.

Table (1): Description of Demographic Characters among Study Group.

\begin{tabular}{|c|c|c|}
\hline Variables & \multicolumn{2}{|c|}{$\begin{array}{l}\text { Number } \\
(n=169)\end{array}$} \\
\hline Age groups & n. & $(\%)$ \\
\hline Less than 30 years old & 61 & $36.1 \%$ \\
\hline From 31 to 40 years old & 89 & $52.7 \%$ \\
\hline From 41 and over & 19 & $11.2 \%$ \\
\hline Total & 169 & $100.0 \%$ \\
\hline
\end{tabular}




\begin{tabular}{|c|c|c|}
\hline Educational level & n. & $(\%)$ \\
\hline Neither read nor write & 14 & $8.3 \%$ \\
\hline Intermediate level & 125 & $74.0 \%$ \\
\hline University & 29 & $17.2 \%$ \\
\hline Training experience & 1 & $0.6 \%$ \\
\hline Total & 169 & $100.0 \%$ \\
\hline Gender & n. & $(\%)$ \\
\hline Male & 146 & $86.4 \%$ \\
\hline Female & 23 & $13.6 \%$ \\
\hline Total & 169 & $100.0 \%$ \\
\hline Place of residence & n. & $(\%)$ \\
\hline The countryside & 50 & $29.6 \%$ \\
\hline The city & 119 & $70.4 \%$ \\
\hline Total & 169 & $100.0 \%$ \\
\hline $\begin{array}{l}\text { The number of years of } \\
\text { work in the food industry }\end{array}$ & n. & $(\%)$ \\
\hline one year & 11 & $6.5 \%$ \\
\hline $1-5$ years & 31 & $18.3 \%$ \\
\hline 6- 10 years & 99 & $58.6 \%$ \\
\hline more than 10 years & 28 & $16.6 \%$ \\
\hline Total & 169 & $100.0 \%$ \\
\hline
\end{tabular}

Food vendors included in the study, table (2) showed that $(85.2 \%)$ had awareness about food safety, (78.1\%) of them thought that food should not sever with bare hands. (66.3\%) of them prepared and cooked the food in 
the same location as the sale. (40.8\%) of study group hired someone in preparing food. $(63.3 \%)$ of them prepare food in the morning and all the day of selling, and (28.4\%) of them prepared on demand. $(54.4 \%)$ of study group found that the peak of vending food is midmorning. All vendors had awareness that food borne diseases may be associated with the consumption of contaminated foods. This finding is similar to the findings of Abdalla et al. (2008) where the results showed the absence of formal training and most of the vendors increased their knowledge of food handling and cooking skills by them self, in addition some of them gained their knowledge through observation or taught by their parents, self-taught.

Table (2): Food Contamination Knowledge Exhibited by Street Food Vendors in Aswan City.

\begin{tabular}{|c|c|c|}
\hline Variables & n. & $(\%)$ \\
\hline \multicolumn{3}{|c|}{ Are you aware of food safety? } \\
\hline Yes & 25 & $85.2 \%$ \\
\hline No & 144 & $14.8 \%$ \\
\hline Total & 169 & $100.0 \%$ \\
\hline \multicolumn{3}{|c|}{ Is food served with bare hands? } \\
\hline Yes & 37 & $21.9 \%$ \\
\hline No & 132 & $78.1 \%$ \\
\hline Total & 169 & $100.0 \%$ \\
\hline \multicolumn{3}{|c|}{ Is food prepared and cooked in the same location as the sale? } \\
\hline Yes & 112 & $66.3 \%$ \\
\hline No & 57 & $33.7 \%$ \\
\hline Total & 169 & $100.0 \%$ \\
\hline \multicolumn{3}{|c|}{ Who does the preparation of foods for vending? } \\
\hline (1) Self & 78 & $46.2 \%$ \\
\hline
\end{tabular}




\begin{tabular}{|c|c|c|}
\hline (2) Family members/relatives & 22 & $13.0 \%$ \\
\hline (3) Hired help & 69 & $40.8 \%$ \\
\hline Total & 169 & $100.0 \%$ \\
\hline \multicolumn{3}{|l|}{ When do you cook foods? } \\
\hline (1) Night before selling & 14 & $8.3 \%$ \\
\hline (2) Morning of selling & 52 & $30.8 \%$ \\
\hline (3) During day & 55 & $32.5 \%$ \\
\hline (4) On demand & 48 & $28.4 \%$ \\
\hline Total & 169 & $100.0 \%$ \\
\hline \multicolumn{3}{|c|}{ When is your peak vending time? } \\
\hline (1) Morning & 54 & $32.0 \%$ \\
\hline (2) Midmorning & 92 & $54.4 \%$ \\
\hline (3) Evening & 23 & $13.6 \%$ \\
\hline Total & 169 & $100.0 \%$ \\
\hline \multicolumn{3}{|c|}{$\begin{array}{l}\text { Are you aware that foodborne diseases may be associated with } \\
\text { the consumption of contaminated foods? }\end{array}$} \\
\hline Yes & 169 & $100.0 \%$ \\
\hline No & 0 & $0.0 \%$ \\
\hline Total & 169 & $100.0 \%$ \\
\hline
\end{tabular}

In assessment of food vendors awareness about COVID-19; the study showed in table (3) that (66.3\%) had enough information about viruses, especially Coronavirus, (53.8\%) had sufficient information about virus transmission methods and $(64.5 \%)$ were aware about the symptoms of Coronavirus, finally $(6.5 \%)$ of them mention that they infected with the 
Coronavirus or felt its symptoms. With mean score ranged between 1.88 and 3.57. This corresponds to Ismail et al. (2016) where he said that the attitudes of street food vendors toward the principles for the prevention and control of foodborne diseases. 
Table (3): Covid-19 Awareness.

\begin{tabular}{|c|c|c|c|c|c|c|c|c|}
\hline \multirow{2}{*}{\multicolumn{2}{|c|}{ Element }} & $\begin{array}{l}\text { Strongly } \\
\text { agree }\end{array}$ & Agree & $\begin{array}{l}\text { I do not } \\
\text { know }\end{array}$ & $\begin{array}{l}\text { Not } \\
\text { agree }\end{array}$ & $\begin{array}{l}\text { Strongly } \\
\text { disagree }\end{array}$ & \multirow[t]{2}{*}{ Mean } & \multirow{2}{*}{$\begin{array}{c}\text { Std. } \\
\text { deviation }\end{array}$} \\
\hline & & N. (\%) & N. (\%) & N. (\%) & N. (\%) & N. $(\%)$ & & \\
\hline 1 & $\begin{array}{l}\text { You have enough } \\
\text { information about viruses, } \\
\text { especially Coronavirus. }\end{array}$ & $13(7.7 \%)$ & $\begin{array}{c}99 \\
(58.6 \%)\end{array}$ & $\begin{array}{c}37 \\
(21.9 \%)\end{array}$ & $12(7.1 \%)$ & $8(4.7 \%)$ & 3.57 & 0.91 \\
\hline 2 & $\begin{array}{l}\text { You have sufficient } \\
\text { information about virus } \\
\text { transmission methods. }\end{array}$ & $21(12.4 \%)$ & $70(41.4 \%)$ & $\begin{array}{c}36 \\
(21.3 \%)\end{array}$ & $\begin{array}{c}25 \\
(14.8 \%)\end{array}$ & $17(10.1 \%)$ & 3.31 & 1.17 \\
\hline 3 & $\begin{array}{l}\text { You are aware of the } \\
\text { symptoms of Coronavirus. }\end{array}$ & $7(4.1 \%)$ & $\begin{array}{c}102 \\
(60.4 \%)\end{array}$ & $29(17.2)$ & $\begin{array}{c}19 \\
(11.2 \%)\end{array}$ & $12(7.1 \%)$ & 3.43 & 0.99 \\
\hline 4 & $\begin{array}{l}\text { You infected with the } \\
\text { Coronavirus or felt its } \\
\text { symptoms. }\end{array}$ & - & $11(6.5 \%)$ & $\begin{array}{c}25 \\
(14.8 \%)\end{array}$ & $\begin{array}{c}67 \\
(39.6 \%)\end{array}$ & $66(39.1 \%)$ & 1.88 & 0.88 \\
\hline
\end{tabular}


Health Practices for Food Handlers during pandemic from vendors' pointed of view in table (4), $(75.8 \%)$ of them thought that good practice should be frequent use of alcoholic hand sanitizers, Using gloves and changed it frequently $(55.7 \%)$ agreed about that, $(38.5 \%)$ mentioned that single-use masks used frequently. (54.5\%) of vendors agreed about washing hands after gloves and masks removed to avoid contamination of food. (71.6\%) to avoid touching the mouth and eyes when wearing gloves and masks. $62.2 \%$ to maintain a distance of at least 1 meter (3 feet) between co-workers or clients. (35.5\%) to see medical advice is sought during the practice of food handlers so that they are safe to handle food. This corresponds to Al-Shabib et al. (2015) where he said that $(83 \%)$ agreed that frequent hand washing is necessary and worth the effort. Street vendors from high density areas (66\%) were more likely to agree with this as opposed to (34\%) in the regions with a low proportion of SFVs. Almost all the street food vendors (90\%) agreed that keeping surfaces clean was important. Most of study group agreed by (87.5\%) about that ensure outer clothing is clean and suitable for handling food; Fingernails kept short and clean (89.9\%), Cleaning and frequent disinfection of work surfaces and touch points are carried out frequently $(90.5 \%)$. Avoid close contact with anyone who has symptoms of respiratory illnesses such as coughing and sneezing represent $(86.3 \%)$. Almost all of vendors agreed about covering the mouth and nose when cough or sneeze. Dispose of tissues and washing hands $(97.5 \%)$, .Hands are washed immediately after entering the toile $(96.4 \%)$, do not spit, smoke, or use tobacco in food preparation areas $(95.9 \%)$, do not do any other unhealthy practices such as touching the nose, mouth or hair while preparing food $(99.4 \%)$. More than half of group agreed about these practice, limit jewellery (such as rings) when handling food (69.2\%), Personal items (phones, etc.) are stored away from food preparation areas $(55.7 \%)$, Hands are washed before starting or handling food frequently $(43.2 \%)$, Hands are washed immediately after smoking, coughing or sneezing, using a tissue or tissue, or eating or drinking. (61.5\%), Hands are washed between handling raw and ready-to-eat foods $(79.9 \%)$, do not eat, sneeze or cough on uncovered food (5.4\%), out come to work when you have a fever, stomach upset, or diarrhea $(8.9 \%)$, Wearing a hat or head covering when serving food $(10.1 \%)$. With mean score ranged between 2.73 and 4.43. This is consistent with Al Suwaidi et al. (2015) where he emphasized that the positive attitude was not supported when asked about self-reported behaviors and when observed during food preparation for practice of hygienic principles. This was on the basis that only $21 \%$ used gloves when touching raw, unwrapped food. Predictors of the use of gloves were educational level and attending training courses. The authors suggested that emphasis should continue on improving knowledge and control of foodborne diseases amongst food handlers. 
Table (4): Health Practices for Food Handlers in Light of the COVID-19 Pandemic

\begin{tabular}{|c|c|c|c|c|c|c|c|c|}
\hline \multirow{2}{*}{\multicolumn{2}{|c|}{ Element }} & $\begin{array}{l}\text { Strongly } \\
\text { agree }\end{array}$ & Agree & $\begin{array}{l}\text { I do not } \\
\text { know }\end{array}$ & $\begin{array}{c}\text { Not } \\
\text { agree }\end{array}$ & $\begin{array}{l}\text { Strongly } \\
\text { disagree }\end{array}$ & \multirow[t]{2}{*}{ Mean } & \multirow{2}{*}{$\begin{array}{c}\text { Std. } \\
\text { deviation }\end{array}$} \\
\hline & & N. $(\%)$ & N. $(\%)$ & N. $(\%)$ & N. $(\%)$ & N. $(\%)$ & & \\
\hline 1 & $\begin{array}{l}\text { Frequent use is made of alcoholic } \\
\text { hand sanitizers. }\end{array}$ & $54(32.0 \%)$ & $\begin{array}{c}74 \\
(43.8 \%)\end{array}$ & - & $\begin{array}{c}15 \\
(8.9 \%)\end{array}$ & $26(15.4 \%)$ & 3.68 & 1.40 \\
\hline 2 & $\begin{array}{l}\text { You have good respiratory health } \\
\text { (covering the mouth and nose } \\
\text { when coughing or sneezing, } \\
\text { disposing of tissues and washing } \\
\text { hands). }\end{array}$ & $78(46.2 \%)$ & $\begin{array}{c}87 \\
(51.5 \%)\end{array}$ & $4(2.4 \%)$ & - & - & 4.43 & 0.54 \\
\hline 3 & $\begin{array}{l}\text { Cleaning and frequent } \\
\text { disinfection of work surfaces and } \\
\text { touch points are carried out } \\
\text { frequently. }\end{array}$ & $49(29.0 \%)$ & $\begin{array}{c}104 \\
(61.5 \%)\end{array}$ & - & $8(4.7 \%)$ & $8(4.7 \%)$ & 4.05 & 0.95 \\
\hline 4 & $\begin{array}{l}\text { Avoid close contact with anyone } \\
\text { who has symptoms of respiratory } \\
\text { illnesses such as coughing and } \\
\text { sneezing. }\end{array}$ & $59(34.9 \%)$ & $\begin{array}{c}87 \\
(51.5 \%)\end{array}$ & $\begin{array}{c}23 \\
(13.6 \%)\end{array}$ & - & - & 4.21 & 0.66 \\
\hline 5 & $\begin{array}{l}\text { Gloves are used and changed } \\
\text { frequently. }\end{array}$ & $29(17.2 \%)$ & $\begin{array}{c}65 \\
(38.5 \%)\end{array}$ & $\begin{array}{c}17 \\
(10.1 \%)\end{array}$ & $\begin{array}{c}40 \\
(23.7 \%)\end{array}$ & $18(10.7 \%)$ & 3.27 & 1.29 \\
\hline
\end{tabular}


International Journal of Tourism and Hospitality Management Volume 3, Issue 2, December 2020

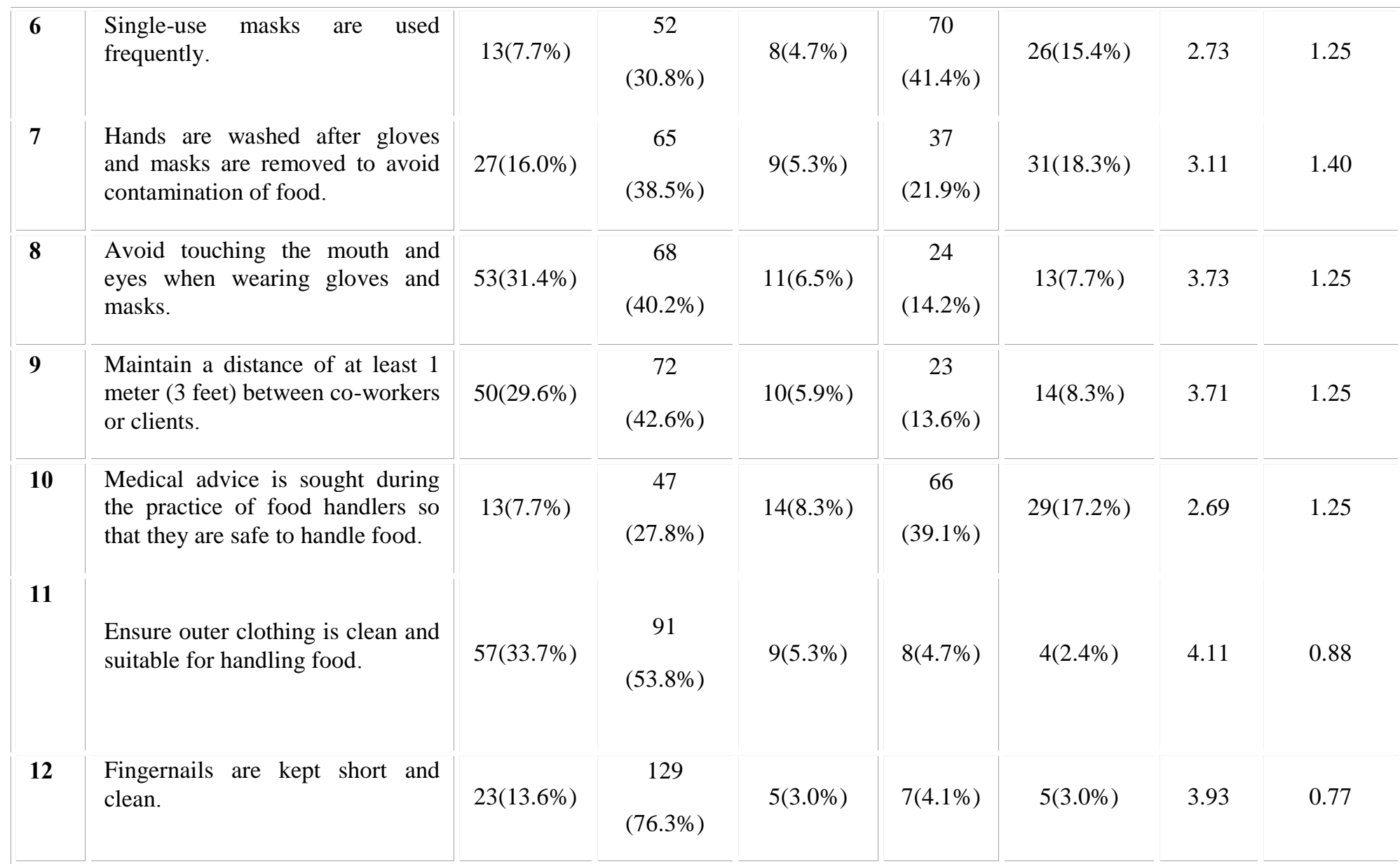




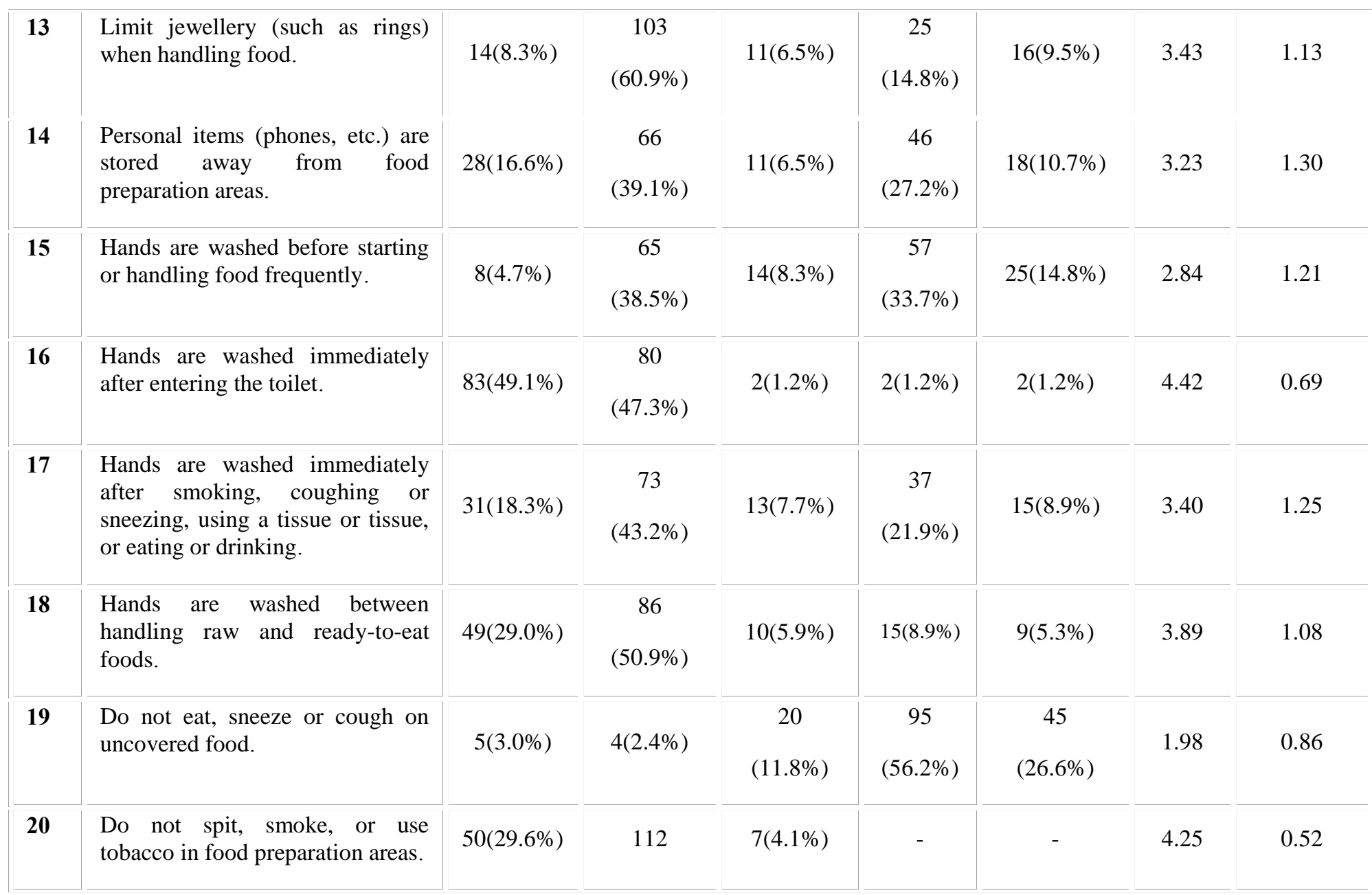




\begin{tabular}{|c|c|c|c|c|c|c|c|c|}
\hline & & & $(66.3 \%)$ & & & & & \\
\hline 21 & $\begin{array}{l}\text { Do not do any other unhealthy } \\
\text { practices such as touching the } \\
\text { nose, mouth or hair while } \\
\text { preparing food. }\end{array}$ & $40(23.7 \%)$ & $\begin{array}{c}128 \\
(75.7 \%)\end{array}$ & $1(0.6 \%)$ & - & - & 4.23 & 0.43 \\
\hline 22 & $\begin{array}{l}\text { You come to work when you have } \\
\text { a fever, stomach upset, or } \\
\text { diarrhoea. }\end{array}$ & $3(1.8 \%)$ & $12(7.1 \%)$ & $2(1.2 \%)$ & $\begin{array}{c}102 \\
(60.4 \%)\end{array}$ & $50(29.6 \%)$ & 1.91 & 0.86 \\
\hline 23 & $\begin{array}{l}\text { Wearing a hat or head covering } \\
\text { when serving food. }\end{array}$ & $6(3.6 \%)$ & $11(6.5 \%)$ & $9(5.3 \%)$ & $\begin{array}{c}64 \\
(37.9 \%)\end{array}$ & $79(46.7 \%)$ & 1.82 & 1.03 \\
\hline
\end{tabular}

Table (5) showed that transportation and delivery of food ingredients and food products (91.7\%) of food vendors mentioned that food received from certified and registered food companies, it received in clean, intact and undamaged packaging (98.9\%), food suppliers are aware of the long distance when making deliveries and passing deliveries to customers (96.4\%). Food is cleaned, disinfected and protected from contamination, and it is separated from other goods that may cause contamination $(86.4 \%)$ and $(34.4 \%)$ mentioned that food suppliers are supplied with alcohol hand sanitizer and paper towels. With mean score ranged between 2.78 and 4.44. This finding is similar to the findings of Tong et al. (2020). 
Table (5): Transportation and Delivery of Food Ingredients and Food Products in Light of the COVID-19 Pandemic.

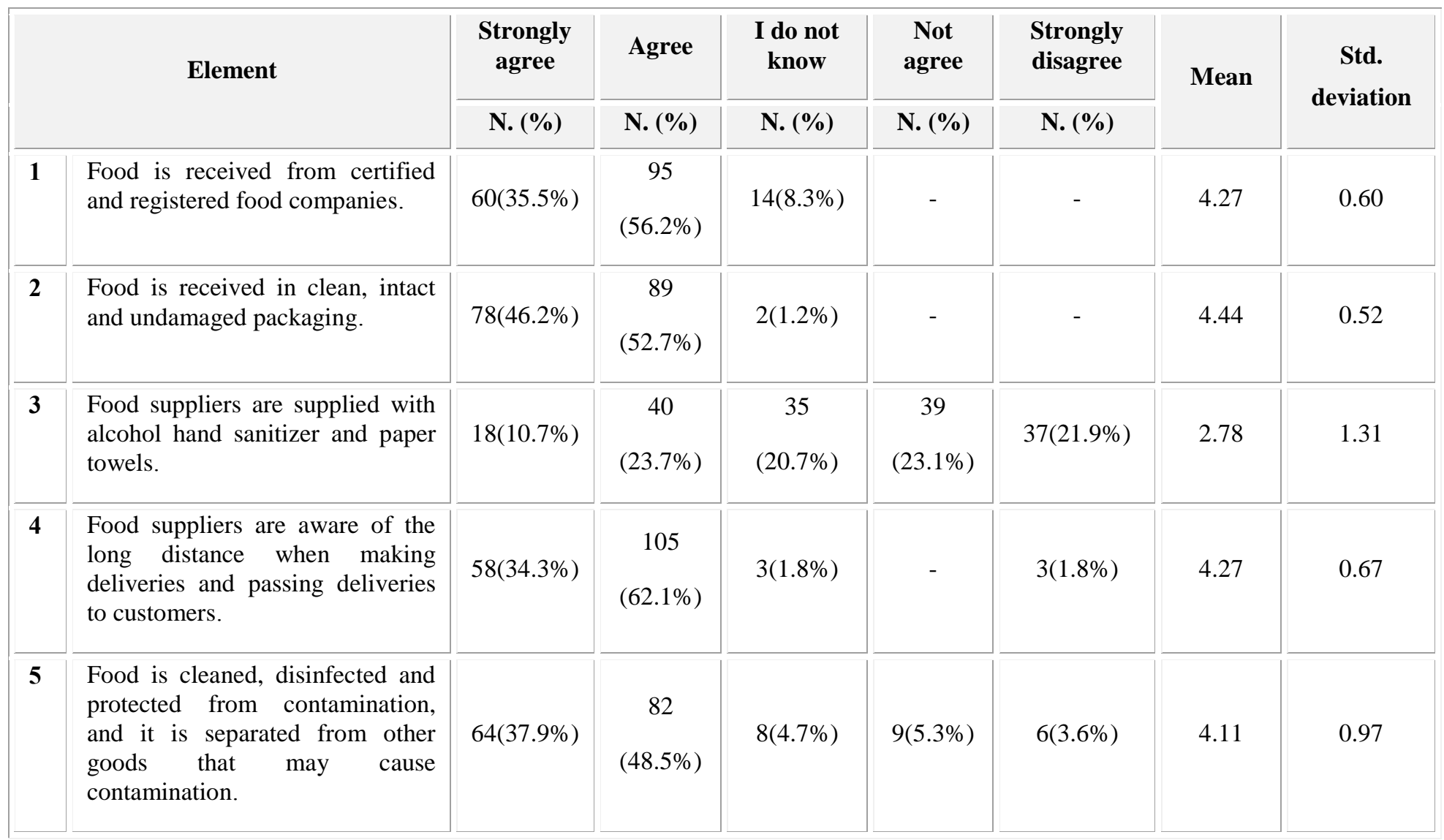


During the pandemic, the study showed in table (6) that (69.9\%) of vendors agreed about that during selling food pincers, ladles, clean gloves used to handle ready-to-eat food to avoid touching food by hand. All the study group verify that all foods washed in clean water before use, do not place ready-to-eat foods on a dirty surface; and food contaminated with microbes through contact with unsafe foods. (97.6\%) of them use soap and water to kill all harmful microbes. Other surfaces that contact with food cleaned and disinfected (93.4\%). A percentage of (72.2\%) agreed about using sterilize with a disinfectant to kill any remaining bacteria. (87.6\%) said sufficient number of litter and waste bins provided. With mean score ranged between 3.67 and 4.44. This is consistent with Omemo and Aderouju (2008) where he said that a study on food hygiene of caregivers also showed a poor relation between knowledge, behavioral and sanitary practices. Furthermore in a study conducted in Mauritius on 50 street food vendors, it was reported that despite the efforts of Health Inspectors in promoting the risks of poor hygiene practices, and an awareness of hygienic conditions, the majority were not putting their knowledge into practice as they perceived their products to be of low risk.

Table (6): Where to Sell Food during the COVID-19 Pandemic

\begin{tabular}{|c|c|c|c|c|c|c|c|c|}
\hline \multicolumn{2}{|r|}{ Element } & $\begin{array}{l}\text { Strongly } \\
\text { agree }\end{array}$ & Agree & $\begin{array}{l}\text { I do not } \\
\text { know }\end{array}$ & $\begin{array}{l}\text { Not } \\
\text { agree }\end{array}$ & $\begin{array}{l}\text { Strongly } \\
\text { disagree }\end{array}$ & Mean & $\begin{array}{c}\text { Std. } \\
\text { deviation }\end{array}$ \\
\hline 1 & $\begin{array}{l}\text { Pincers, ladles, clean gloves, } \\
\text { etc. are used to handle ready-to- } \\
\text { eat food to avoid touching food } \\
\text { by hand. }\end{array}$ & $52(30.8 \%)$ & $\begin{array}{c}66 \\
(39.1 \%)\end{array}$ & $10(5.9 \%)$ & $\begin{array}{c}26 \\
(15.4 \%)\end{array}$ & $15(8.9 \%)$ & 3.67 & 1.29 \\
\hline 2 & $\begin{array}{l}\text { Verify that all foods are washed } \\
\text { in clean water before use. }\end{array}$ & $52(30.8 \%)$ & $\begin{array}{c}117 \\
(69.2 \%)\end{array}$ & - & - & - & 4.30 & 0.46 \\
\hline
\end{tabular}




\begin{tabular}{|c|c|c|c|c|c|c|c|c|}
\hline 3 & $\begin{array}{l}\text { Do not place ready-to-eat foods } \\
\text { on a dirty surface. }\end{array}$ & $66(39.1 \%)$ & $\begin{array}{c}103 \\
(60.9 \%)\end{array}$ & - & - & - & 4.39 & 0.48 \\
\hline 4 & $\begin{array}{l}\text { Food can be contaminated with } \\
\text { microbes through contact with } \\
\text { unsafe foods. }\end{array}$ & $75(44.4 \%)$ & $\begin{array}{c}94 \\
(55.6 \%)\end{array}$ & - & - & - & 4.44 & 0.49 \\
\hline 5 & $\begin{array}{l}\text { Use soap and water to kill all } \\
\text { harmful microbes. }\end{array}$ & $70(41.4 \%)$ & $\begin{array}{c}95 \\
(56.2 \%)\end{array}$ & $4(2.4 \%)$ & - & - & 4.39 & 0.53 \\
\hline 6 & $\begin{array}{l}\text { Other surfaces that come into } \\
\text { contact with food are cleaned } \\
\text { and disinfected. }\end{array}$ & $50(29.6 \%)$ & $\begin{array}{c}108 \\
(63.9 \%)\end{array}$ & $11(6.5 \%)$ & - & - & 4.23 & 0.55 \\
\hline 7 & $\begin{array}{l}\text { Sterilize with a disinfectant to } \\
\text { kill any remaining bacteria (the } \\
\text { manufacturer and instructions or } \\
\text { food safety program for chlorine } \\
\text { solution are to be followed). }\end{array}$ & $45(26.6 \%)$ & $\begin{array}{c}77 \\
(45.6 \%)\end{array}$ & $20(11.8 \%)$ & $16(9.5 \%)$ & $11(6.5 \%)$ & 3.76 & 1.14 \\
\hline 8 & $\begin{array}{l}\text { Sufficient number of litter and } \\
\text { waste bins is provided. }\end{array}$ & $54(32.0 \%)$ & $\begin{array}{c}94 \\
(55.6 \%)\end{array}$ & $16(9.5 \%)$ & $3(1.8 \%)$ & $2(1.2 \%)$ & 4.15 & 0.75 \\
\hline
\end{tabular}




\section{Second: Analysis of a Consumer Questionnaire}

Among study group of the study in table (7), (55.7\%) were aged less than 30 years, (37.2\%) between 31 and 40, (7.1\%) aged above 41 years old. As regards educational level $(81.7 \%)$ educated to university level, $(50.5 \%)$ of them were females, $(36.5 \%)$ of them were students and $(36.2 \%)$ were employers, $(14.6 \%)$ worked in private sector, $(7.7 \%)$ were university professors, and (1.2\%) worked as doctors. (20.4\%) had income less than 1000 pounds / month, (33.7\%) earn between 1000 to 2000 pounds, and (28.2\%) earn between 2000 and 3000 pounds monthly. $(56.3 \%)$ of them were married. This is consistent with the results of (Kealesitse and Kabama, 2012) where emphasized the results showed that consumers with a lower level of education tend to be less concerned about certain food safety factors compared to those with a higher level of education. The respondents with higher food expenditures were also more concerned about food safety than those who spent less money on food.

Table (7): Description of Demographic Characters among Study Group.

\begin{tabular}{|c|c|c|}
\hline \multicolumn{1}{|c|}{ Variables } & \multicolumn{2}{|c|}{ Number } \\
\hline Age groups & $\mathbf{( n = 3 2 3 )}$ \\
\hline Less than 30 years old & 180 & $\mathbf{( \% )}$ \\
\hline From 31 to 40 years & 120 & $55.7 \%$ \\
\hline old & 23 & $37.2 \%$ \\
\hline From 41 and over & 323 & $7.1 \%$ \\
\hline Total & $\mathbf{( n . )}$ & $100 \%$ \\
\hline Educational level & 0 & $\mathbf{( \% )}$ \\
\hline Neither read nor write & 29 & $9 \%$ \\
\hline Intermediate level & 264 & $9.3 \%$ \\
\hline University & 30 & $100 \%$ \\
\hline Postgraduate & 323 & $9.7 \%$ \\
\hline Total & & \\
\hline
\end{tabular}




\begin{tabular}{|c|c|c|}
\hline Gender & (n.) & $(\%)$ \\
\hline Male & 160 & $49.5 \%$ \\
\hline Female & 163 & $50.5 \%$ \\
\hline Total & 323 & $100 \%$ \\
\hline Occupation & (n.) & $(\%)$ \\
\hline Student & 118 & $36.5 \%$ \\
\hline Government employee & 117 & $36.2 \%$ \\
\hline Private sector employee & 47 & $14.6 \%$ \\
\hline University doctor & 25 & $7.7 \%$ \\
\hline Doctor & 4 & $1.2 \%$ \\
\hline Others & 12 & $3.7 \%$ \\
\hline Total & 323 & $100 \%$ \\
\hline Monthly income & (n.) & $(\%)$ \\
\hline Less than 1000 EGP & 66 & $20.4 \%$ \\
\hline 1000-2000 EGP & 109 & $33.7 \%$ \\
\hline 2000-3000 EGP & 91 & $28.2 \%$ \\
\hline 3000-5000 EGP & 33 & $10.2 \%$ \\
\hline More than 5000 EGP & 24 & $7.4 \%$ \\
\hline Total & 323 & $100 \%$ \\
\hline Marital Status & (n.) & $(\%)$ \\
\hline Married & 182 & $56.3 \%$ \\
\hline Unmarried & 141 & $43.7 \%$ \\
\hline Total & 323 & $100 \%$ \\
\hline
\end{tabular}


Participants enrolled in the study in table (8) showed that $(14.6 \%)$ of them study in area of food safety, (13.6\%) take training courses in food safety and health, and all of them buy from street vendors, and aware that food borne diseases could be transmitted through food consumption, and $(42.7 \%)$ of them felt ill effects from eating through the practices of street food vendors. Consumers had little knowledge of who was responsible for food safety in Aswan; therefore educating consumers on who was responsible for food safety in Aswan may help mitigate consumers' concerns.

\section{Table (8): Consumers' Food Safety Knowledge in Aswan City in Light of the Coronavirus Pandemic.}

\begin{tabular}{|c|c|c|}
\hline Variables & Yes & No \\
\hline $\begin{array}{l}\text { Do you work or study in any area of } \\
\text { food safety? }\end{array}$ & $47(14.6 \%)$ & $276(85.4 \%)$ \\
\hline $\begin{array}{l}\text { Did you take training courses in food } \\
\text { safety and health? }\end{array}$ & $44(13.6 \%)$ & $279(86.4 \%)$ \\
\hline Do you buy from street vendors? & $323(100.0 \%)$ & $0(0.0 \%)$ \\
\hline $\begin{array}{l}\text { Are you aware that foodborne diseases } \\
\text { may be transmitted through food } \\
\text { consumption? }\end{array}$ & $323(100.0 \%)$ & $0(0.0 \%)$ \\
\hline $\begin{array}{l}\text { Have you ever felt any ill effects from } \\
\text { eating through the practices of street } \\
\text { food vendors? }\end{array}$ & $138(42.7 \%)$ & $185(57.3 \%)$ \\
\hline
\end{tabular}

As regards food safety concerns for consumers, table (9) showed that about $(67.8 \%)$ of participants were between strongly agree and agree in concern about the safety of food purchased from street food vendors, (26.7\%) thought that food safety regulations protect adequately. All of them liked to see stronger food safety standards imposed. Also (95.6\%) of them pay more for a product with an above average food safety level. But only (4.7\%) did not eat food prepared by someone outside the home, (89.8\%) believed that it is common for people to contract viruses, especially Coronavirus from food sold on the street through the practices of food vendors. (75.2\%) bought food from sellers without certified healthy/food badges. (83.2\%) checked labels and expiration dates when purchasing food products, (86\%) inspected damaged food packaging, unpleasant odors and altered meat are thoroughly before purchase. With mean score ranged between 1.62 and 4.88 . 
Table (9): Food Safety Concerns for Consumers in Light of the Coronavirus Pandemic.

\begin{tabular}{|c|c|c|c|c|c|c|c|c|}
\hline \multirow{2}{*}{\multicolumn{2}{|c|}{ Item }} & $\begin{array}{l}\text { Strongly } \\
\text { agree }\end{array}$ & Agree & $\begin{array}{c}\text { I do } \\
\text { not } \\
\text { know }\end{array}$ & disagree & $\begin{array}{l}\text { Strongly } \\
\text { disagree }\end{array}$ & \multirow{2}{*}{ Mean } & \multirow{2}{*}{$\begin{array}{c}\text { Std. } \\
\text { deviation }\end{array}$} \\
\hline & & No. $(\%)$ & No. $(\%)$ & $\begin{array}{l}\text { No. } \\
(\%)\end{array}$ & No. $(\%)$ & No. $(\%)$ & & \\
\hline 1 & $\begin{array}{l}\text { I am concerned about the } \\
\text { safety of food purchased } \\
\text { from street food vendors. }\end{array}$ & $76(23.5 \%)$ & $\begin{array}{c}143 \\
(44.3 \%)\end{array}$ & - & $57(17.6 \%)$ & $47(14.6 \%)$ & 3.44 & 1.39 \\
\hline 2 & $\begin{array}{l}\text { I think food safety } \\
\text { regulations protect me } \\
\text { adequately. }\end{array}$ & $39(12.1 \%)$ & $47(14.6 \%)$ & $\begin{array}{c}123 \\
(38.1 \%)\end{array}$ & $48(14.9 \%)$ & $66(20.4 \%)$ & 2.82 & 1.25 \\
\hline 3 & $\begin{array}{l}\text { I would like to see stronger } \\
\text { food safety standards } \\
\text { imposed. }\end{array}$ & $\begin{array}{c}287 \\
(88.9 \%)\end{array}$ & $36(11.1 \%)$ & - & - & - & 4.88 & 0.31 \\
\hline 4 & $\begin{array}{l}\text { I would pay more for a } \\
\text { product with an above } \\
\text { average food safety level. }\end{array}$ & $\begin{array}{c}283 \\
(87.6 \%)\end{array}$ & $26(8.0 \%)$ & - & $8(2.5 \%)$ & $6(1.9 \%)$ & 4.77 & 0.74 \\
\hline 5 & $\begin{array}{l}\text { I don't eat food prepared by } \\
\text { someone outside the home. }\end{array}$ & $8(2.5 \%)$ & $7(2.2 \%)$ & - & $\begin{array}{c}149 \\
(46.1 \%)\end{array}$ & $\begin{array}{c}159 \\
(49.2 \%)\end{array}$ & 1.62 & 0.81 \\
\hline 6 & I believe that it is common & 258 & $32(9.9 \%)$ & 33 & - & - & 4.69 & 0.64 \\
\hline
\end{tabular}




\begin{tabular}{|c|c|c|c|c|c|c|c|c|}
\hline & $\begin{array}{l}\text { for people to contract } \\
\text { viruses, especially } \\
\text { Coronavirus, from food } \\
\text { sold on the street through } \\
\text { the practices of food } \\
\text { vendors. }\end{array}$ & $(79.9 \%)$ & & $(10.2 \%)$ & & & & \\
\hline 7 & $\begin{array}{l}\text { I buy food from sellers } \\
\text { without certified healthy / } \\
\text { food badges. }\end{array}$ & $\begin{array}{c}207 \\
(64.1 \%)\end{array}$ & $36(11.1 \%)$ & $5(1.5 \%)$ & $43(13.3 \%)$ & $32(9.9 \%)$ & 4.06 & 1.44 \\
\hline 8 & $\begin{array}{l}\text { I check labels and } \\
\text { expiration dates when } \\
\text { purchasing food products. }\end{array}$ & $\begin{array}{c}212 \\
(65.6 \%)\end{array}$ & $57(17.6 \%)$ & - & $22(6.8 \%)$ & $32(9.9 \%)$ & 4.22 & 1.33 \\
\hline 9 & $\begin{array}{l}\text { Damaged food packaging, } \\
\text { unpleasant odors and } \\
\text { altered meat thoroughly } \\
\text { inspected before purchase. }\end{array}$ & $\begin{array}{c}200 \\
(61.9 \%)\end{array}$ & $78(24.1 \%)$ & $\begin{array}{c}42 \\
(13.0 \%)\end{array}$ & $2(0.6 \%)$ & $1(0.3 \%)$ & 4.46 & 0.76 \\
\hline
\end{tabular}

The study showed in table (10) that about (4\%) of participants were between strongly agreed and agreed about that the overall level of awareness of street food handlers about food safety is good. All participants agreed about degree of awareness of the practices of street food vendors and the extent of the Coronavirus spread is bad. (21.9\%) said vendors appear clean. Also (3.1\%) mentioned that Street food vendors frequently wash their hands before, during, and after preparing and serving food to them. All participants thought that Vendor not appropriately dressed. Only (3.4\%) of them mentioned that Street food vendors use alcohol-based hand sanitizers. (1.9\%) agreed about food handlers use gloves that change frequently, and (15.8\%) found that food handlers keep a distance between them and customers. However, $(0.3 \%)$ of participants mentioned that street food handlers use a thermometer to check the temperature of foods. As regards 
observation of fever, disorder or other disease on street food handlers when serving food (9.3\%) agreed about it. No participants agreed about Street food handlers wore a hat or head covering when serving food. Only (1.5\%) of participants thought street food handlers disinfect cutting boards after each use, (38.4\%) Food vendors use pincers to handle food and (98.4\%) the seller handles cash without using gloves. With mean score ranged between 1 and 4.85 . This is consistent with Al-Sakkaf (2012) where he emphasized that in assessing the factors influencing the safety and quality of street food in a rural area in Limpopo examined the knowledge, attitude and perceptions in both street food vendors and consumers. Her findings indicated that the majority of street food vendors and consumers had little information regarding the proper preparation and storage of food as well as environmental conditions that may be detrimental to health. Furthermore $64.4 \%$ of consumers thought that street food is sold under unacceptable conditions and these needed improvement.

Table (10): The Level of Awareness and Evaluation of Street Food Vendors' Practices in Light of the Coronavirus Pandemic.

\begin{tabular}{|c|c|c|c|c|c|c|c|c|}
\hline \multicolumn{2}{|r|}{ Item } & $\begin{array}{c}\begin{array}{c}\text { Strongly } \\
\text { agree }\end{array} \\
\text { N. }(\%)\end{array}$ & $\begin{array}{l}\text { Agree } \\
\text { N. }(\%)\end{array}$ & $\begin{array}{c}\begin{array}{c}\text { I do } \\
\text { not } \\
\text { know }\end{array} \\
\text { N. (\%) }\end{array}$ & $\begin{array}{l}\text { disagree } \\
\text { N. }(\%)\end{array}$ & 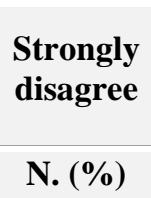 & Mean & $\begin{array}{c}\text { Std. } \\
\text { deviation }\end{array}$ \\
\hline 1 & $\begin{array}{l}\text { Your assessment of the overall } \\
\text { level of awareness of street food } \\
\text { handlers about food safety in } \\
\text { general is good. }\end{array}$ & - & $\begin{array}{c}13 \\
(4.0 \%)\end{array}$ & $\begin{array}{c}24 \\
(7.4 \%)\end{array}$ & $\begin{array}{c}152 \\
(47.1 \%)\end{array}$ & $\begin{array}{c}134 \\
(41.5 \%)\end{array}$ & 1.73 & 0.76 \\
\hline 2 & $\begin{array}{l}\text { The degree of awareness of the } \\
\text { practices of street food vendors and } \\
\text { the extent of the Coronavirus } \\
\text { spread is good. }\end{array}$ & - & - & $\begin{array}{c}24 \\
(7.4 \%)\end{array}$ & $\begin{array}{c}141 \\
(43.7 \%)\end{array}$ & $\begin{array}{c}158 \\
(48.9 \%)\end{array}$ & 1.58 & 0.62 \\
\hline
\end{tabular}


International Journal of Tourism and Hospitality Management Volume 3, Issue 2, December 2020

\begin{tabular}{|c|c|c|c|c|c|c|c|c|}
\hline 3 & Vendors appear clean. & $7(2.2 \%)$ & $\begin{array}{c}48 \\
(14.9 \%)\end{array}$ & $\begin{array}{c}17 \\
(5.3 \%)\end{array}$ & $99(30.7 \%)$ & $\begin{array}{c}152 \\
(47.1 \%)\end{array}$ & 1.94 & 1.14 \\
\hline 4 & $\begin{array}{l}\text { Street food vendors frequently } \\
\text { wash their hands before, during, } \\
\text { and after preparing and serving } \\
\text { food to you. }\end{array}$ & $1(0.3 \%)$ & $9(2.8 \%)$ & $\begin{array}{c}14 \\
(4.3 \%)\end{array}$ & $85(26.3 \%)$ & $\begin{array}{c}214 \\
(66.3 \%)\end{array}$ & 1.44 & 0.73 \\
\hline 5 & Vendor appropriately dressed. & - & - & $\begin{array}{c}8 \\
(2.5 \%)\end{array}$ & $51(15.8 \%)$ & $\begin{array}{c}264 \\
(81.7 \%)\end{array}$ & 1.20 & 0.46 \\
\hline 6 & $\begin{array}{l}\text { Street food vendors use alcohol- } \\
\text { based hand sanitizers. }\end{array}$ & - & $11(3.4 \%)$ & $\begin{array}{c}6 \\
(1.9 \%)\end{array}$ & $37(11.5 \%)$ & $\begin{array}{c}269 \\
(83.3 \%)\end{array}$ & 1.25 & 0.65 \\
\hline 7 & $\begin{array}{l}\text { Food handlers use gloves that } \\
\text { change frequently. }\end{array}$ & - & $6(1.9 \%)$ & $\begin{array}{c}7 \\
(2.2 \%)\end{array}$ & $22(6.8 \%)$ & $\begin{array}{c}288 \\
(89.2)\end{array}$ & 1.16 & 0.54 \\
\hline 8 & $\begin{array}{l}\text { Food handlers keep a distance } \\
\text { between them and you. }\end{array}$ & $3(0.9 \%)$ & $\begin{array}{c}48 \\
(14.9 \%)\end{array}$ & $\begin{array}{c}2 \\
(0.6 \%)\end{array}$ & $20(6.2 \%)$ & $\begin{array}{c}250 \\
(77.4 \%)\end{array}$ & 1.55 & 1.12 \\
\hline 9 & $\begin{array}{l}\text { Street food handlers use a } \\
\text { thermometer to constantly check } \\
\text { the temperature of foods. }\end{array}$ & - & $1(0.3 \%)$ & $\begin{array}{c}6 \\
(1.9 \%)\end{array}$ & $6(1.9 \%)$ & $\begin{array}{c}310 \\
(96.0 \%)\end{array}$ & 1.06 & 0.34 \\
\hline 10 & $\begin{array}{l}\text { A fever, disorder or other disease } \\
\text { has been observed on street food } \\
\text { handlers when serving food. }\end{array}$ & $3(0.9 \%)$ & $27(8.4 \%)$ & $\begin{array}{c}28 \\
(8.7 \%)\end{array}$ & $40(12.4 \%)$ & $\begin{array}{c}225 \\
(69.7 \%)\end{array}$ & 1.58 & 1.01 \\
\hline 11 & $\begin{array}{l}\text { Street food handlers wear a hat or } \\
\text { head covering when serving food. }\end{array}$ & - & - & - & - & $\begin{array}{c}323 \\
(100.0 \%)\end{array}$ & 1.00 & 0.00 \\
\hline 12 & Street food handlers disinfect & - & $5(1.5 \%)$ & 19 & $47(14.6 \%)$ & 252 & 1.30 & 0.65 \\
\hline
\end{tabular}




\begin{tabular}{|c|c|c|c|c|c|c|c|c|}
\hline & cutting boards after each use. & & & $(5.9 \%)$ & & $(78.0 \%)$ & & \\
\hline 13 & $\begin{array}{l}\text { Food vendors use pincers to handle } \\
\text { food. }\end{array}$ & $20(6.2 \%)$ & $\begin{array}{c}104 \\
(32.2 \%)\end{array}$ & $\begin{array}{c}10 \\
(3.1 \%)\end{array}$ & $76(23.5 \%)$ & $\begin{array}{c}113 \\
(35.0 \%)\end{array}$ & 2.51 & 1.40 \\
\hline 14 & $\begin{array}{l}\text { The seller handles cash without } \\
\text { using gloves. }\end{array}$ & $\begin{array}{c}282 \\
(87.3 \%)\end{array}$ & $\begin{array}{c}36 \\
(11.1 \%)\end{array}$ & $\begin{array}{c}5 \\
(1.5 \%)\end{array}$ & - & - & 4.85 & 0.39 \\
\hline
\end{tabular}

In table (11), when study the changes in consumers' habits of consuming food on the street from street food vendors in Light of the COVID-19 pandemic, (50.8\%) of participants try to eat low-fat foods frequently, (93.5\%) of them try to buy safe food that is free of pesticides, hormones, and chemicals. Also (97.3\%) try to buy non-contaminated canned food from guaranteed street food vendors and $(87.3 \%)$ try to consume foods that are free of toxic chemicals and heavy metals like mercury and lead. Around (92.8\%) try to consume fresh, healthy foods and they bought from reliable, hygienic and high quality food vendors. When eating out, $(32.5 \%)$ use single-use dining table utensils from street food vendors. Before starting to eat food on the street, $(29.7 \%)$ washed hands with soap and water. With mean score ranged between 2.33 and 4.79 . 
Table (11): Changes in Consumers' Habits of Consuming Food on the Street from Street Food Vendors in Light of the COVID-19 Pandemic.

\begin{tabular}{|c|c|c|c|c|c|c|c|c|}
\hline \multicolumn{2}{|r|}{ Item } & \multirow{2}{*}{$\begin{array}{c}\text { Very } \\
\text { infrequently } \\
\text { N. }(\%) \\
115 \\
(35.6 \%)\end{array}$} & \multirow{2}{*}{$\begin{array}{c}\text { Scarcely } \\
\begin{array}{c}\text { N. (\%) } \\
49 \\
(15.2 \%)\end{array}\end{array}$} & \multirow{2}{*}{$\begin{array}{c}\text { Not sure } \\
\text { N. }(\%) \\
38 \\
(11.8 \%)\end{array}$} & \multirow{2}{*}{$\begin{array}{c}\text { Frequently } \\
\begin{array}{c}\text { N. }(\%) \\
88 \\
(27.2 \%)\end{array}\end{array}$} & \multirow{2}{*}{$\begin{array}{c}\begin{array}{c}\text { Very } \\
\text { frequently }\end{array} \\
\text { N. }(\%) \\
33 \\
(10.2 \%)\end{array}$} & \multirow{2}{*}{$\begin{array}{c}\text { Mean } \\
3.38\end{array}$} & \multirow{2}{*}{$\begin{array}{c}\text { Std. } \\
\text { deviation } \\
1.45\end{array}$} \\
\hline 1 & I try to eat low-fat foods frequently. & & & & & & & \\
\hline 2 & $\begin{array}{l}\text { I try to buy safe food that is free of } \\
\text { pesticides, hormones, and chemicals. }\end{array}$ & $277(85.8 \%)$ & $25(7.7 \%)$ & $21(6.5 \%)$ & - & - & 4.79 & 0.54 \\
\hline 3 & $\begin{array}{l}\text { I try to buy non-contaminated canned } \\
\text { food from guaranteed street food } \\
\text { vendors. }\end{array}$ & $267(82.7 \%)$ & $\begin{array}{c}47 \\
(14.6 \%)\end{array}$ & $9(2.8 \%)$ & - & - & 4.79 & 0.46 \\
\hline 4 & $\begin{array}{l}\text { I try to consume foods that are free of } \\
\text { toxic chemicals and heavy metals like } \\
\text { mercury and lead. }\end{array}$ & $260(80.5 \%)$ & $\begin{array}{c}22 \\
(6.8 \%)\end{array}$ & $\begin{array}{c}41 \\
(12.7 \%)\end{array}$ & - & - & 4.67 & 0.68 \\
\hline 5 & $\begin{array}{l}\text { I try to consume fresh, healthy foods } \\
\text { and they are bought from reliable, } \\
\text { hygienic and high quality food } \\
\text { vendors. }\end{array}$ & $250(77.4 \%)$ & $\begin{array}{c}51 \\
(15.8 \%)\end{array}$ & $22(6.8 \%)$ & - & - & 4.70 & 0.58 \\
\hline 6 & $\begin{array}{l}\text { When eating out, use single-use } \\
\text { dining table utensils from street food } \\
\text { vendors. }\end{array}$ & $49(15.2 \%)$ & $\begin{array}{c}56 \\
(17.3 \%)\end{array}$ & $14(4.3 \%)$ & $\begin{array}{c}106 \\
(32.8 \%)\end{array}$ & $98(30.3 \%)$ & 2.54 & 1.45 \\
\hline 7 & $\begin{array}{l}\text { Before starting to eat food on the } \\
\text { street, hands are washed with soap } \\
\text { and water. }\end{array}$ & $29(9.0 \%)$ & $\begin{array}{c}67 \\
(20.7 \%)\end{array}$ & $4(1.2 \%)$ & $\begin{array}{c}107 \\
(33.1 \%)\end{array}$ & $\begin{array}{c}116 \\
(35.9 \%)\end{array}$ & 2.33 & 1.37 \\
\hline
\end{tabular}


Table (12) showed that, in assessment of Awareness of the pathogens transmitted through the practices of street food vendors in Light of the COVID-19 pandemic, (80.8\%) were fully aware of the causes and methods of transmission of diseases and viruses through the practices of street food vendors. Most of them (90.4\%) heard about food safety problems and $(86.7 \%)$ had awareness about outbreaks of food borne pathogens, $(2.7 \%)$ of them mention that one of household has been diagnosed with a disease transmitted through the practices of food vendors. As regards spread of the Coronavirus (71.6\%) of participants believed that contamination of food with microorganisms is a serious food safety problem and causes the. All participants thought that safe handling of food is an important part of my responsibilities. Most of participants thought that healthy people could cause disease by carrying the germs to food $(87.3 \%)$. The appearance, smell, and taste of the food considered as if food is danger in (93.2\%) of participants. Almost all participants thought that believe that the Coronavirus can spread through food through the practices of street food vendors (98.8\%).with mean score ranged between 2.32 and 4.95 .

Table (12): Awareness of the Pathogens Transmitted through the Practices of Street Food Vendors in Light of the COVID-19 Pandemic.

\begin{tabular}{|c|c|c|c|c|c|c|c|c|}
\hline \multicolumn{2}{|r|}{ Item } & $\begin{array}{c}\text { Strongly } \\
\text { agree }\end{array}$ & Agree & $\begin{array}{c}\text { I do not } \\
\text { know }\end{array}$ & disagree & $\begin{array}{l}\text { Strongly } \\
\text { disagree }\end{array}$ & \multirow{2}{*}{$\begin{array}{r}\text { Mean } \\
3.92\end{array}$} & \multirow{2}{*}{$\begin{array}{c}\begin{array}{c}\text { Std. } \\
\text { deviation }\end{array} \\
1.08\end{array}$} \\
\hline 1 & $\begin{array}{l}\text { You are fully aware of the causes and } \\
\text { methods of transmission of diseases } \\
\text { and viruses through the practices of } \\
\text { street food vendors. }\end{array}$ & $\begin{array}{c}102 \\
(31.6 \%)\end{array}$ & $\begin{array}{c}159 \\
(49.2 \%)\end{array}$ & $14(4.3 \%)$ & $33(10.2 \%)$ & $15(4.6 \%)$ & & \\
\hline 2 & I heard about food safety problems. & $\begin{array}{c}201 \\
(62.2 \%)\end{array}$ & $\begin{array}{c}91 \\
(28.2 \%)\end{array}$ & $17(5.3 \%)$ & $11(3.4 \%)$ & $3(0.9 \%)$ & 4.47 & 0.82 \\
\hline 3 & $\begin{array}{l}\text { You are aware of any outbreaks of } \\
\text { foodborne pathogens. }\end{array}$ & $\begin{array}{c}236 \\
(73.1 \%)\end{array}$ & $\begin{array}{c}44 \\
(13.6 \%)\end{array}$ & $15(4.6 \%)$ & $14(4.3 \%)$ & $14(4.3 \%)$ & 4.46 & 1.06 \\
\hline
\end{tabular}




\begin{tabular}{|c|c|c|c|c|c|c|c|c|}
\hline 4 & $\begin{array}{l}\text { Anyone else in your household has } \\
\text { been diagnosed with a disease or virus } \\
\text { transmitted through the practices of } \\
\text { food vendors. }\end{array}$ & $13(4.0 \%)$ & $28(8.7 \%)$ & $\begin{array}{c}113 \\
(35.0 \%)\end{array}$ & $\begin{array}{c}66 \\
(20.4 \%)\end{array}$ & $\begin{array}{c}103 \\
(31.9 \%)\end{array}$ & 2.32 & 1.12 \\
\hline 5 & $\begin{array}{l}\text { She believes that contamination of } \\
\text { food with microorganisms, such as } \\
\text { germs, is a serious food safety } \\
\text { problem and causes the spread of the } \\
\text { Coronavirus. }\end{array}$ & $90(27.9 \%)$ & $\begin{array}{c}141 \\
(43.7 \%)\end{array}$ & $92(28.5 \%)$ & - & - & 3.99 & 0.75 \\
\hline 6 & $\begin{array}{l}\text { Safe handling of food is an important } \\
\text { part of my responsibilities. }\end{array}$ & $\begin{array}{c}176 \\
(54.5 \%)\end{array}$ & $\begin{array}{c}147 \\
(45.5 \%)\end{array}$ & - & - & - & 4.54 & 0.49 \\
\hline 7 & $\begin{array}{l}\text { Healthy people can cause disease by } \\
\text { carrying the germs to food. }\end{array}$ & $\begin{array}{c}239 \\
(74.0 \%)\end{array}$ & $\begin{array}{c}43 \\
(13.3 \%)\end{array}$ & $\begin{array}{c}41 \\
(12.7 \%)\end{array}$ & - & - & 4.61 & 0.70 \\
\hline 8 & $\begin{array}{l}\text { You can tell if a food is dangerous to } \\
\text { eat by its appearance, smell, or taste. }\end{array}$ & $\begin{array}{c}246 \\
(76.2 \%)\end{array}$ & $\begin{array}{c}55 \\
(17.0 \%)\end{array}$ & $20(6.2 \%)$ & $1(0.3 \%)$ & $1(0.3 \%)$ & 4.68 & 0.62 \\
\hline 9 & $\begin{array}{l}\text { You believe that the Coronavirus can } \\
\text { spread through food through the } \\
\text { practices of street food vendors. }\end{array}$ & $\begin{array}{c}311 \\
(96.3 \%)\end{array}$ & $8(2.5 \%)$ & $4(1.2 \%)$ & - & - & 4.95 & 0.26 \\
\hline
\end{tabular}


The study found that although vendors and consumers demonstrated basic knowledge of food safety In light of the Corona pandemic, the criteria did not emphasize basic hygiene practices such as hand washing, cleaning of utensils, washing of raw vegetables, and quality of ingredients. Instead, four main food selection criteria could be identified and were related to (1) aesthetic appearance of food and food stand, (2) appearance of the food vendor, (3) interpersonal trust in the vendor, and (4) consumers often chose to accessibility of food. This finding is similar to the findings of Kealesitse and Kabama (2012). Hence, consumers relied on risk voidance strategies by assessing neatness, appearance, and trustworthiness of vendor. Vendors were also found to emphasize appearance while selling and to ignore core food safety practices while preparing food.

\section{CONCLUSION}

The prevalence of COVID-19 commonly known as Corona virus among food handlers and the general community in country, and the increasing menace of COVID-19 is indeed a community health problem. This study generally observed that $(85.2 \%)$ had awareness about food safety. While, food vendors were only concerned with profit creation at the expense of standard food hygiene and sanitary practices. This study found that the emphasis on appearances, and presentation of food and individual trust in vendor-consumer interactions and practices were the most important parameters In light of the Coronavirus pandemic for assessing the practices While handling food among customers and vendors of street food in Aswan. This study provided direct assessment on the contamination of street foods, and on the effect of environmental conditions and hygiene practices on the street foods, served in Aswan city. In fact, $(75.8 \%)$ of them thought that good practice should be frequent use of alcoholic hand sanitizers, Using gloves and changed it frequently (55.7\%) agreed about that. Moreover, this study highlighted the lack of food handling knowledge among street food vendors, and the inadequacy of environmental surroundings of vending sites. Street vendors from high density areas $(66 \%)$ were more likely to agree with this as opposed to (34\%) in the regions with a low proportion of SFVs. These reported problems constitute a burden on the community health and expenses, but present an opportunity to set a series of actions to prevent potential outbreaks by ameliorating the quality of street foods. This study linked the occurred pathogens to specific mishandlings and practices of street foods vendors. While, customers enrolled in the study showed that $(14.6 \%)$ of them study in area of food safety, $(13.6 \%)$ take training courses in food safety and health, and all of them buy from street 
vendors, and aware that food borne diseases could be transmitted through food consumption.

\section{RECOMMENDATIONS}

(1) Developing of standards and legislations for street food activities.

(2) Providing allowed educational seminars to the community and awareness for street food vendors and customers about food safety.

(3) Establishing proper environmental for street foods selling places.

(4) Conducting regular and assessment audits by qualified workers.

(5) The government should aware the community on importance of food safety and health practices and advice of not to obtaining foods in unclean sources or areas.

(6) The Ministry of health and specialized state agencies should ensure that regular teaching sessions are conducted for health workers involved in the monitoring and assessment of street food vendors.

(7) It is required to coordinate the efforts of all sectors involved in this area, so as to permit a complete solution that will ensure the consumers receive goods posing no significant health risk.

(8) Mass media communications should be convincing to the customers, leading them to an understanding of the health problems involved and causing them to demand developed quality from street food vendors.

\section{REFERENCES}

Abdalla, M., Suleiman, S., Alien, Y. \& Bakheit, O. (2008). Food Safety Knowledge and Practices of Street Food Vendors in Khartoum City. Sudan J. Vet Sci Anim Husb, 47(182), 123-136.

Abdalla, M., Suliman, S. \& Bakhiet, A. (2009). Food Safety Knowledge and Practices of Street Food Vendors in Atbara City (Naher Elneel State Sudan). African Journal of Biotechnology, 8, 6967-6971.

Al Suwaidi, A., Hussein, H., Al Faisal, W., El Sawaf, E. \& Wasfy, A. (2015). Hygienic Practices among Food Handlers. Dubai, Int J Prev Med Res, 1(3), 101-8.

Alekhya, S., Varanasi, B., Subba, R. \& Sudershan, R. (2017). Identifying Critical Risk Practices among Street Food Handlers. British Food Journal, 119(2), 390-400. 
Al-Sakkaf, A. (2012). Evaluation of Food Handling Practice among New Zealanders and other Developed Countries as a Main Risk Factor for Campy Lobacteriosis Rate. Food Control, 27(2), 330-7.

Al-Shabib, N., Mosilhey, S. \& Husain, F. (2015). Cross-Sectional Study on Food Safety Knowledge, Attitude and Practices of Male Food Handlers Employed in Restaurants of King Saud University, Saudi Arabia. Food Control, 59, 212-217.

Bruce, k. \& colleen, T. (2013). Street Food around the World: An Encyclopedia of Food and Culture. Santa Barbara, California, Acid-free paper, Manufactured in the United States of America.

Chada, R. \& Mamidi, B. (2012). Street Food System in India in the Context of Global Change: Lessons for Policy. Paper Presented at the International Conference on Strength Based Practice in Social Work and Human Services, Kathmandu, 22-24.

Choudhury, M., Mahanta, L., Goswami, J., Mazumder, M. \& Pegoo, B. (2011). Socioeconomic Profile and Food Safety Knowledge and Practice of Street Food Vendors in the City of Guwahati, Assam, India. Food Control, 22, 196-203.

Dun-Dery, E. \& Addo, H. (2016). Food Hygiene Awareness, Processing and Practice among Street Food Vendors in Ghana. Food Public Health, 6(3), 65-74.

Galgamuwa, L., Iddawela, D. \& Dharmaratne, S. (2016). Knowledge and Practices of Food Hygiene among Food Handlers in Plantation Sector. Sri Lanka, Int J Sci Rep., 2(12), 304-11.

Giuffrida, A. (2019). Mummified remains of 35 ancient Egyptians found in Aswan. The Guardian. ISSN 0261-3077. Archived from the Original.

Hamed, A. \& Mohammed, N. (2020). Food Safety Knowledge, Attitude and Self-Reported Practices among Food Handlers. Sohag, Egypt, East Mediterr Health J., 26(4), 374-381.

Ismail, F., Chik, C., Muhammad, R. \& Yusoff, N. (2016). Food Safety Knowledge and Personal Hygiene Practices Amongst Mobile Food Handlers. Shah Alam, Selangor, Procedia-Social and Behavioral Sciences, 222, 290-298.

Iwu, A., Uwakwe, K., Duru, C., Diwe, K., Chineke, H. \& Merenu, I. (2017). Knowledge, Attitude and Practices of Food Hygiene among Food Vendors. Owerri, Imo State, Nigeria, Occup Dis Environ Med., 5(1), 11-5. 
Joanna, T., Eleftherios, H. \& Wojciech, K. (2017). Evaluation of Street Food Vendors' Hygienic Practices Using Fast Observation Questionnaire. Elsevier Ltd, All Rights Reserved, Food Control, 80, 350-359.

Kealesitse, B. \& Kabama, I. (2012). Exploring the Influence of Quality and Safety on Consumers' Food Purchase Decisions. Botswana, International Journal of Business Administration, 3, 90-97.

Medical, C., Ansk, K., Singh, a., Lt Col, P., Maj, N. \& Air, C. (2016). Impact of Health Education Intervention on Food Safety and Hygiene of Street Vendors: A pilot Study. Elsevier B.V. on Behalf of Director General, Armed Forces Medical Services, Medical journal armed forces, India, 72, 265-269.

Muinde, O. \& Kuria, E. (2005). Hygienic and Sanitary Practices of Vendors of Street Foods in Nairobi, Kenya. Afr J Food Agric Nutr Dev, 5(1), 1-13.

Okojie, P. \& Isah, E. (2014). Sanitary Conditions of Food Vending Sites and Food Handling Practices of Street Food Vendors in Benin City, Nigeria: Implication for Food Hygiene and Safety. J Environ Public Health, 4(1): http://dx.doi.org/10.1155/2014/701316.

Omemo, A. \& Aderouju, S. (2008). Food Safety Knowledge and Practices of Street Food Vendors. Abeokuta, Nigeria, Food Control, 19 (4), 396-402.

Pokhrel, B., Pokhrel, K., Chhetri, M., Awate, R. \& Sah, N. (2016). Knowledge, Attitude and Practice Regarding Food Hygiene among Food Handlers: a Cross-Sectional Study. Janaki Medical College J Med Sci., 3(1), 14-9.

Rane, S. (2011). Street Vended Food in Developing World: Hazard Analyses. Indian, Journal of Microbiology, 51(1), 100-106.

Samapundo, S., Climat, R., Xhaferi, R. \& Devlieghere, F. (2015). Food Safety Knowledge, Attitudes and Practices of Street Food Vendors and Consumers in Port-au-Prince. Food Control, Haiti, 50, 457466.

Sani, N. \& Siow, O. (2014). Knowledge, Attitudes and Practices of Food Handlers on Food Safety in Food Service Operations at the University Kebangsaan. Malaysia, Food Control, 37, 210-7.

Smith \& Melanie, K. (2016). Issues in Cultural Tourism Studies. Routledge. ISBN 9781138785694. OCLC 932058870.

Son, R., Mohhiddin, O., Toh, P. \& Chai, L. (2015). Food Court Hygiene Assessment and Food Safety Knowledge, Attitudes and Practices of Food Handlers in Putrajaya. Int Food Res J., 22(5), 1843-54. 
Thakur, C., Mehra, R., Narula, C., Mahapatra, S. \& Kalita, T. (2013). Food Safety and Hygiene Practices among Street Vendors in Delhi, India. Int J Curr Res., 5(1), 3531-3534.

Tong, Z., Tang, A., Li, K., Li, P., Wang, H. \& Yi, J. (2020). Potential Presymptomatic Transmission of SARS-CoV-2. Zhejiang Province, China, Emerg Infect Dis., doi:10.3201/eid2605.200198

Woh, P., Thong, K., Behnke, J., Lewis, J. \& Zain, S. (2016). Evaluation of Basic Knowledge on Food Safety and Food Handling Practices among Migrant Food Handlers in Peninsular Malaysia. Food Control, 70, 64-73.

World Health Organization (WHO) (2020). COVID-19 and Food Safety: Guidance for Food Businesses, Interim Guidance, Food and Agriculture Organization of the United Nations.

Yu, P., Zhu, J., Zhang, Z. \& Han, Y. (2020). A Familial Cluster of Infection Associated with the 2019 Novel Coronavirus Indicating Possible Person-to-Person Transmission during the Incubation Period.

Zengran, L., Guangyi, Z. \& Xiangmei, Z. (2014). Urban Street Foods in Shijiazhuang City, China: Current Status, Safety Practices and Risk Mitigating Strategies. Elsevier Ltd. All Rights Reserved, Food Control, Shijiazhuang, China, 41, 212-218. 